\title{
Preliminary Assessment of Avian Diversity of Ayede Wetland in Ekiti State, Nigeria
}

\section{Ogunyemi 00* \\ Department of Forest Resources and Wildlife Management, Ekiti State University, Nigeria}

*Corresponding author: Ogunyemi 00, Department of Forest Resources and Wildlife Management, Ekiti State University, Ado-Ekiti, Nigeria, Email: olumideogunyemi80@yahoo. com

\section{Research Article}

Volume 4 Issue 7

Received Date: November 08, 2020

Published Date: December 05, 2020

DOI: $10.23880 /$ jenr- 16000223

\section{Abstract}

Avifauna diversity of Ayede wetland, in Ekiti State, Nigeria was evaluated between January 2008 and December 2009 . A total of seven- three (73) bird species belonging to fifteen (15) orders and twenty-four (24) families were recorded. Out of these, sixty-six (66) were resident and seven (7) were migratory. Water birds constitute $20.55 \%$ of the total number of birds observed while $79.45 \%$ were terrestrial birds. The order Passeriformes constituted the predominant group, representing $23.3 \%$ of families $(n=7)$ and $31.9 \%$ of species $(n=23)$. The results further shows an estimated population of nine hundred and fifty -nine (959) individuals from seventy-three (73) bird species inhabiting the wetland. Among bird species, adapted to the wetland, Slender- billed Weaver, African-black Kite, Shelley's Francolin, and Black- headed Weaver were prominent. It was concluded that Ayede wetland is important as bird habitat and that conservation of considerable area of surrounding vegetation may provide adequate protection for the wetland birds in the area.

Keywords: Conservation; Wetlands; Vegetation; Abundance

\section{Introduction}

The Nigerian Avifauna is rich and diverse as the environment itself. This is because Nigeria is such a large country, stretching from the beaches and Mangrove swamps of the Gulf of Guinea through the remnants of the rainforest to the Savannas and thorn scrub of the North, which provides habitat for a fascinating variety of birds. Birds are important component of many ecosystems, even though their biomass is usually less than that of mammals. Nigeria has some of the most beautiful and interesting birds in the world. Ogunyemi \& Olujobi [1] reported that Nigeria possesses high diversity of birds in West African sub-region and that the various ecosystems provide niche for diverse species of birds. In Ekiti State, Nigeria, the vegetation and wetlands contain a diverse avifauna resource. Although formerly abundant, many species have become rare and may be threatened with extinction. In physical terms, the last two decades have witnessed an accelerated rate of habitat destruction. This results principally from a combination of population expansion and direct government action. Birds' population and distribution especially in the wetlands have been affected by this unprecedented rate of habitat destruction. Clergeau, et al. [2] asserted that rapid increase in the alteration of natural habitats is the main threat to the forests and wetlands biodiversity. Many specialist species inhabiting an ecosystem are unable to adapt to disturbed environment [3]. The preparation of checklist of birds inhabiting an area is basic to the study of bird diversity [4,5]. It is a well-known fact that the concentration of threatened bird species is greater in the tropics than in other continents of the world. Of the 1,029 threatened species, 884 occur in developing countries [6]. Thus the conservation of threatened bird species has to be properly addressed in the development nations of the world, if the threatened species are to continue their existence. The objective of the present study was to investigate the species 


\section{Journal of Ecology and Natural Resources}

composition, abundance and distribution of bird species inhabiting the Ayede wetland, Ekiti State, Nigeria in order to facilitate the development of comprehensive management plans for efficient and effective conservation of birds in the area.

\section{Materials and Methods}

The wetland of Ayede is the specific site where the present study was carried out. Ayede Ekiti lies within the tropics and geographically located between $7^{\circ} 40^{\prime} \mathrm{N}$ to $5^{\circ}$ $15^{\prime}$ East of Greenwich meridian. The climate of the wetland area is tropical, with average temperature of $25^{\circ} \mathrm{C}$ all year round and high relative humidity. The annual rainfall varies from about $2500 \mathrm{~mm}$ to $4000 \mathrm{~mm}$ in the area. The pattern of rainfall distribution is unimodal with a long rainy season between April and October with a peak in August. The area is not protected and cultivation is carried out around the wetland. The wetland is typified by woodland vegetation and is characterized by remnants of forest, savanna tree and shrub species which co-exist side by side. The herb layer is dominated by grass and scattered trees. The trees are small with twisted boles. As a result of the arrival of savanna species, especially grassy materials which are highly inflammable in dry season, bush burning has become a major factor around the wetland. The most frequently occurring grass species in the wetland are Aristida kerstingii, Eleusine coracana, Eragrotis tenella, Sporobolus paniculatus.

A preliminary survey was carried out in the month of January 2008. The physical features of the study area were assessed using ground survey. The geographical coordinates of the study site was taken. The study was conducted from January, 2008 to December 2009, which includes wet and dry seasons in the area.

\section{Bird Assessment}

A survey of abundance and diversity of Avifauna species of Ayede wetland associated with a dam was carried out using transects count method as described by Burnham, et al. [7]. The stratified random sampling technique was followed for studying birds in the wetland, as described Thakur [8] which involved the division of sites into different strata, based upon vegetation type and habitat. The strata were stratified to circumnavigate the area according to habitat types and the sampling unit within the habitat was determined and assigned on the basis of area coverage and vegetation types. The method involved the establishment of twenty (20) transects of $1 \mathrm{Km}$ in length and $2 \mathrm{~m}$ width placed to circumnavigate the wetland. Birds were observed by walking along the established transects in the wetland for three consecutive days in a month throughout the study period. Data were collected when weather conditions were good enough for accurate observation especially during period free of strong rain or strong wind.

Data collection was carried out for five hours a day from 6.30-10.00am in the morning and $4.30-6.00 \mathrm{pm}$ in the evening, when the activities of birds were prominent.

In all transects, a record was made of all the types and the group of bird species in order of detection. The birds were observed with the aid of $10 \times 50$ Nikon binoculars to species level and their taxonomic groups were properly categorized based on field guide to birds of Western Africa [9].

\section{Results and Discussion}

Ayede wetland is situated in the Northern part of Ekiti State, Nigeria. It ranges from $597 \mathrm{~km}$ (length) to $536 \mathrm{~km}$ (width). It is typified by woodland vegetation and is characterized by remnants of forest, savanna tree and shrub species which exist side by side. The wetland is surrounded by agriculture fields, where different crops are grown throughout the year. The remnant of plant and cereal grains left in the area after harvesting attracts bird species to the wetland. The dam premises of the wetland support various species of fishes, amphibians and water insects which serves as food for wetland birds.

A total of 73 bird species belonging to 15 orders and 24 families have been recorded from the study wetland (Table 2). Details such as common and scientific names, status and abundance of the bird species observed in the wetland are presented in Table 1 . Water birds constitute $20.55 \%$ of the total number of birds observed while $79.45 \%$ were terrestrial birds. The order Passeriformes constituted the predominant group, representing $23.3 \%$ of families $(n=7)$ and $31.9 \%$ of species $(n=23)$ (Figure 1$)$. The families with the largest number of species were Accipitridae $(n=12)$. It represented $16.4 \%$ of the total number of bird species inhabiting the wetland of Ayede (Table 2). Out of the totality of 73 bird species observed in the wetland, 66 (90.4\%) were resident and 7 (9.6\%) were migrant species (Table 3 ). Three (3) of migratory species were observed during the wet season while the remaining four (4) migratory species were recorded at the peak of dry season of the study period. Four bird species such as Slender-Billed Weaver (Ploceus pelzelni) African Black kite (Milvus migrans), Shelley's francolin (Francolins shelleyi) and Black-Headed Weaver (Ploceus cucullatus) ranked highest in number in the wetland, while Little Sparrow Hawk (Accipiter minullus), African Marsh Harrier (Circus ranivorus), Lizard Buzzard (Kaupifalco monogrammicus), Yellow Spotted Barbet (Buccanodon duchaillui) and Red Bishop (Euplectes orix) were rarely observed (Table 1). The birds observed were found to inhabit varying habitat types surrounding the wetland. A 
total of 959 individual bird species were counted during the study period of the year 2009 in the wetland. The fairly large number of bird species recorded in Ayede wetland may be as a result of the vegetation heterogeneity which invariably bring about the variation in food, cover availability, and micro-climatic variations. This agrees with the conclusion of Afolayan and Ajayi $(1980)$ and Crowel $[10,11]$ that variation in species composition, abundance and diversity of animals are strongly influenced by the availability of food, water and cover in the habitat. The element of habitat disturbance is not pronounced in Ayede wetland which might be one of factors responsible for high value of bird species diversity recorded in the wetland. Moenting [12] asserted that habitat disturbance creates increased habitat edge, resulting in loss of habitat specialist species from the habitat. Water birds being generally near the top of most wetland food chains have been reported by Jayson and Matthew [13] to be highly susceptible to habitat disturbances and are good biological indicators of general condition of aquatic habitats. Further analysis of the bird species abundance in the wetland indicated that of the bird species that inhabits the wetland, 6 were rare, 1 was common, 39 were uncommon, and 27 bird species were in frequent category (Table 3).

Ayede wetland accommodates more of Waders water birds than swimmers and divers. Tak [14] asserted that Waders water birds represent the greatest species diversity among the water birds. Wader bird species like Little Grebe (Podiceps ruficollis), Night Heron (Nycticorax nycticorax) and Little Bittern (Ixobrychus minutus), that belong to the family Ardeidae were observed regularly wading through the water surface of the wetland.

The wetland dependent bird species such as white faced Tree Duck (Dendrocygna viduata), African fish Eagle (Haliaetus vocifer) Long-crested Eagle (Lophaetus occipitalis) and king fishers were observed throughout study period around Ayede wetland.

The tree species of Lophira alata, Combretum molle, Cola acuminate, Garcini afzelli Phizophora racemosa, Baphia nitida, Parkia biglobosa, Albizia zygia and Spondias mombin present in the wetland environment provide cover to terrestrial residential birds inhabiting the wetland environment.

\begin{tabular}{|c|c|c|c|c|c|c|}
\hline & Order & Family & Common name & Scientific name & Status & Abundance \\
\hline 1 & Pelecaniformes & Phalacrocoracidae & Long-Tailed Cormorant & Phalacrocrax africanus & $\mathrm{R}$ & $\mathrm{F}$ \\
\hline 2 & Podicipediformes & Podicipedidae & Little Grebe & Podicios ruficollis & $\mathrm{I}$ & $\mathrm{F}$ \\
\hline 3 & Ciconiiformes & Ardeidae & Night Heron & Nycticorax nycticorax & $\mathrm{I}$ & $\mathrm{UC}$ \\
\hline 4 & Ciconiiformes & Ardeidae & Little Bittern & Ixobrychus minutus & $\mathrm{I}$ & $\mathrm{F}$ \\
\hline 5 & Ciconiiformes & Ardeidae & Great White Egret & Egretta alba & $\mathrm{R}$ & $\mathrm{F}$ \\
\hline 6 & Ciconiiformes & Ardeidae & Little Egret & Egretta garzetta & $\mathrm{R}$ & $\mathrm{F}$ \\
\hline 7 & Ciconiiformes & Ardeidae & Yellow-Billed Egret & Egretta intermedia & $\mathrm{R}$ & $\mathrm{F}$ \\
\hline 8 & Ciconiiformes & Ardeidae & Cattle Egret & Ardeola ibis & $\mathrm{R}$ & $\mathrm{F}$ \\
\hline 9 & Ciconiiformes & Scopidae & Hamenkop & Scopus umbretta & $\mathrm{R}$ & $\mathrm{F}$ \\
\hline 10 & Ciconiiformes & Scopidae & Black-Headed Heron & Ardea melanocephala & $\mathrm{R}$ & $\mathrm{UC}$ \\
\hline 11 & Anseriformes & Anatidae & White-Faced Tree Duck & Dendrocygona viduata & $\mathrm{I}$ & $\mathrm{F}$ \\
\hline 12 & Falconiformes & Accipitridae & African Fish Eagle & Haliaeetus vocifer & $\mathrm{R}$ & $\mathrm{F}$ \\
\hline 13 & Falconiformes & Accipitridae & Long-Crested Eagle & Lophaetus occipitalis & $\mathrm{R}$ & UC \\
\hline 14 & Falconiformes & Accipitridae & Black kite & Milvus migrans & $\mathrm{R}$ & $\mathrm{UC}$ \\
\hline 15 & Falconiformes & Accipitridae & Little sparrow hawk & Accipiter minullus & $\mathrm{R}$ & $\mathrm{F}$ \\
\hline 16 & Falconiformes & Accipitridae & Great sparrow hawk & Accipiter melanoleucus & $\mathrm{R}$ & RA \\
\hline 17 & Falconiformes & Accipitridae & African marsh Harries & Circus ranivorus & $\mathrm{R}$ & UC \\
\hline 18 & Falconiformes & Accipitridae & Lizard Buzzard & $\begin{array}{c}\text { Kaupifalco } \\
\text { monogrammicus }\end{array}$ & $\mathrm{R}$ & RA \\
\hline 19 & Falconiformes & Accipitridae & Osprey & Pandion haliaetus & $\mathrm{R}$ & RA \\
\hline 20 & Falconiformes & Accipitridae & Gabar Goshawk & Melierax gabar & $\mathrm{R}$ & $\mathrm{UC}$ \\
\hline 21 & Falconiformes & Accipitridae & Lanner & Falco biarmicus & $\mathrm{I}$ & $\mathrm{UC}$ \\
\hline 22 & Falconiformes & Accipitridae & Kestrel & Falco tinnunculus & $\mathrm{R}$ & $\mathrm{UC}$ \\
\hline 23 & Falconiformes & Accipitridae & Grey kestrel & Falco ardosiaceus & $\mathrm{R}$ & $\mathrm{UC}$ \\
\hline
\end{tabular}




\begin{tabular}{|c|c|c|c|c|c|c|}
\hline 24 & Galliformes & Phasianidae & Scaly francolin & Francolinus squamatus & $\mathrm{R}$ & $\mathrm{UC}$ \\
\hline 25 & Galliformes & Phasianidae & Shelley's francolin & Francolinus shelleyi & $\mathrm{R}$ & $\mathrm{F}$ \\
\hline 26 & Galliformes & Phasianidae & Crested francolin & Francolinus sephaena & $\mathrm{R}$ & $\mathrm{F}$ \\
\hline 27 & Galliformes & Numididae & Crested Guineafowl & Guttera edouardi & $\mathrm{R}$ & $\mathrm{F}$ \\
\hline 28 & Galliformes & Numididae & Helmeted Guineafowl & Numida meleagris & $\mathrm{R}$ & $\mathrm{F}$ \\
\hline 29 & Columbiformes & Columbidae & Red-Eye Dove & $\begin{array}{c}\text { Streptopelia } \\
\text { semitorquata }\end{array}$ & $\mathrm{R}$ & $\mathrm{F}$ \\
\hline 30 & Columbiformes & Columbidae & Ring-Necked Dove & Streptopelia capicola & $\mathrm{R}$ & $\mathrm{F}$ \\
\hline 31 & Columbiformes & Columbidae & Dusky Turtle Dove & Streptopelia lugens & $\mathrm{R}$ & $\mathrm{F}$ \\
\hline 32 & Columbiformes & Columbidae & Tambourine Dove & Turtur tympanistria & $\mathrm{R}$ & $\mathrm{UC}$ \\
\hline 33 & Columbiformes & Columbidae & $\begin{array}{c}\text { Emerald-Spotted wood } \\
\text { Dove }\end{array}$ & Turtur chalcospilos & $\mathrm{R}$ & UC \\
\hline 34 & Columbiformes & Columbidae & Green pigeon & Treron australis & $\mathrm{R}$ & $\mathrm{F}$ \\
\hline 35 & Columbiformes & Columbidae & Speckled pigeon & Columba guinea & $\mathrm{R}$ & $\mathrm{UC}$ \\
\hline 36 & Cuculiformes & Cuculidae & White-browed coucal & $\begin{array}{c}\text { Centropus } \\
\text { supercilliosus }\end{array}$ & $\mathrm{R}$ & $\mathrm{UC}$ \\
\hline 37 & Cuculiformes & Cuculidae & Senegal coucal & Centropus senegalensis & $\mathrm{R}$ & $\mathrm{UC}$ \\
\hline 38 & Coraciiformes & Phoeniculidae & Green wood hoopoe & Phoeniculus purpureus & $\mathrm{R}$ & $\mathrm{UC}$ \\
\hline 39 & Musophagiformes & Musophagidae & Ross's turaco & Musophaga rossae & $\mathrm{R}$ & $\mathrm{UC}$ \\
\hline 40 & Musophagiformes & Musophagidae & $\begin{array}{c}\text { Eastern grey plantain } \\
\text { Eater }\end{array}$ & Crinifer zonurus & $\mathrm{R}$ & $\mathrm{UC}$ \\
\hline 41 & Coraciiformes & Alcedinidae & Malachite king fisher & Alcedo cristata & $\mathrm{R}$ & $\mathrm{UC}$ \\
\hline 42 & Coraciiformes & Alcedinidae & Pygmy king fisher & Ispidina picta & $\mathrm{R}$ & $\mathrm{UC}$ \\
\hline 43 & Coraciiformes & Alcedinidae & Dwarf king fisher & Myioceyx lecontei & $\mathrm{R}$ & $\mathrm{UC}$ \\
\hline 44 & Meropidas & Bucerotidae & Trumpeter Hornbill & Bycanistes bucinator & $\mathrm{R}$ & $\mathrm{UC}$ \\
\hline 45 & Meropidas & Bucerotidae & White-crested Hornbill & $\begin{array}{c}\text { Tropicranus } \\
\text { albocristatus }\end{array}$ & $\mathrm{R}$ & $\mathrm{F}$ \\
\hline 46 & Piciformes & Picidae & Grey wood pecker & Mesopicos goertae & $\mathrm{R}$ & $\mathrm{UC}$ \\
\hline 47 & Caprimulgiformes & Caprimulgidae & Abyssinian Nightjar & $\begin{array}{c}\text { Caprimulgus } \\
\text { poliocephalus }\end{array}$ & $\mathrm{R}$ & $\mathrm{UC}$ \\
\hline 48 & Apodiformes & Apodidae & Palm Swift & Cypsiurus parvus & $\mathrm{R}$ & $\mathrm{F}$ \\
\hline 49 & Piciformes & Capitonidae & Yellow-spotted barbet & Buccanodon duchaillui & $\mathrm{R}$ & $\mathrm{RA}$ \\
\hline 50 & Passeriformes & Motacillidae & African pied wagtail & Motacilla capensis & $\mathrm{R}$ & $\mathrm{UC}$ \\
\hline 51 & Passeriformes & Laniidae & Ethiopian swallow & Hirundo aethiopita & $\mathrm{R}$ & $\mathrm{UC}$ \\
\hline 52 & Passeriformes & Laniidae & African rock martin & Hirundo fuligula & $\mathrm{R}$ & $\mathrm{UC}$ \\
\hline 53 & Passeriformes & Nectariniidae & Hunter's sunbird & Nectarinia hunteri & $\mathrm{R}$ & $\mathrm{UC}$ \\
\hline 54 & Passeriformes & Nectariniidae & Amethyst sunbird & Nectarinia amethystine & $\mathrm{R}$ & $\mathrm{F}$ \\
\hline 55 & Passeriformes & Nectariniidae & Olive-Bellied sunbird & Nectarinia chloropygius & $\mathrm{R}$ & $\mathrm{F}$ \\
\hline 56 & Passeriformes & Nectariniidae & $\begin{array}{l}\text { Eastern Double-collard } \\
\text { sunbird }\end{array}$ & Nectarinia mediocris & $\mathrm{R}$ & $\mathrm{UC}$ \\
\hline 57 & Passeriformes & Nectariniidae & Beautiful sunbird & Nectarinia pulchella & $\mathrm{R}$ & $\mathrm{UC}$ \\
\hline 58 & Passeriformes & Nectariniidae & Variable sunbird & Nectarinia venusta & $\mathrm{R}$ & $\mathrm{UC}$ \\
\hline 59 & Passeriformes & Nectariniidae & Superb sunbird & Nectarinia superba & $\mathrm{R}$ & $\mathrm{UC}$ \\
\hline 60 & Passeriformes & Nectariniidae & $\begin{array}{l}\text { Blue-Throated Brown } \\
\text { sunbird }\end{array}$ & Nectarinia cyanolaema & $\mathrm{R}$ & UC \\
\hline
\end{tabular}


Journal of Ecology and Natural Resources

\begin{tabular}{|c|c|c|c|c|c|c|}
\hline $\mathbf{6 1}$ & Passeriformes & Ploceidae & Pin-Tailed whydah & Vidua macroura & $\mathrm{R}$ & $\mathrm{UC}$ \\
\hline $\mathbf{6 2}$ & Passeriformes & Ploceidae & Slender-Billed Weaver & Ploceus pelzelni & $\mathrm{I}$ & $\mathrm{C}$ \\
\hline $\mathbf{6 3}$ & Passeriformes & Ploceidae & Grosbeak Weaver & Amblyospiza albifrons & $\mathrm{I}$ & $\mathrm{UC}$ \\
\hline $\mathbf{6 4}$ & Passeriformes & Ploceidae & Vieillot's black weaver & Ploceus nigerrimus & $\mathrm{R}$ & $\mathrm{F}$ \\
\hline $\mathbf{6 5}$ & Passeriformes & Ploceidae & Black-Headed weaver & Ploceus cucullatus & $\mathrm{R}$ & $\mathrm{F}$ \\
\hline $\mathbf{6 6}$ & Passeriformes & Ploceidae & Yellow-mantled weaver & Ploceus tricolor & $\mathrm{R}$ & $\mathrm{UC}$ \\
\hline $\mathbf{6 7}$ & Passeriformes & Ploceidae & Yellow-Backed weaver & Ploceus capitalis & $\mathrm{R}$ & $\mathrm{F}$ \\
\hline $\mathbf{6 8}$ & Passeriformes & Ploceidae & Black-Necked weaver & Ploceus nigricollis & $\mathrm{R}$ & $\mathrm{UC}$ \\
\hline $\mathbf{6 9}$ & Passeriformes & Ploceidae & Grey-Headed sparrow & Passer griseus & $\mathrm{R}$ & $\mathrm{UC}$ \\
\hline $\mathbf{7 0}$ & Passeriformes & Corvidae & Pied crow & Corvus albus & $\mathrm{R}$ & $\mathrm{F}$ \\
\hline $\mathbf{7 1}$ & Passeriformes & Corvidae & Pia piac & Ptilostomus afer & $\mathrm{R}$ & $\mathrm{UC}$ \\
\hline $\mathbf{7 2}$ & Passeriformes & Sturnidae & Splendid glossy starling & $\begin{array}{c}\text { Lamprotornis } \\
\text { splendidus }\end{array}$ & $\mathrm{R}$ & $\mathrm{RA}$ \\
\hline $\mathbf{7 3}$ & Passeriformes & Sturnidae & Red bishop & Euplectes orix & $\mathrm{R}$ & $\mathrm{RA}$ \\
\hline
\end{tabular}

$\mathrm{R}=$ Resident, $\mathrm{I}=\mathrm{R}=$ Resident, $\mathrm{I}=$ Immigrant, $\mathrm{RA}=$ Rare, $\mathrm{C}=$ Common, $\mathrm{UC}=$ Uncommon, $\mathrm{f}=$ frequent Table 1: Wetland Birds Recorded Around Ayede Wetland.

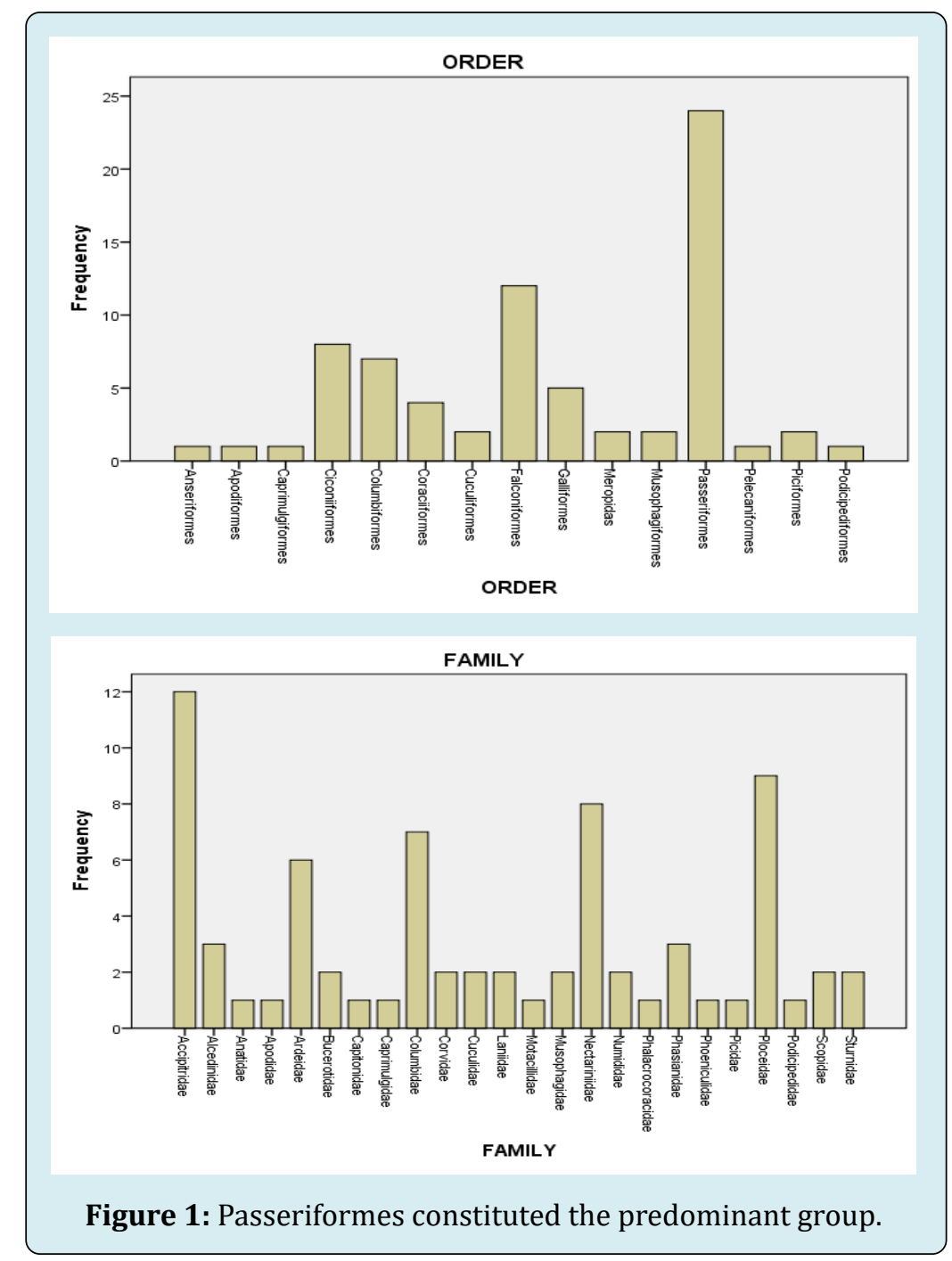




\begin{tabular}{|c|c|c|}
\hline Family & $\begin{array}{c}\text { No of Bird } \\
\text { Species }\end{array}$ & $\begin{array}{c}\text { Percentage } \\
\text { Occurrence }\end{array}$ \\
\hline Accipitridae & 12 & 16.4 \\
\hline Alcedinidae & 3 & 4.1 \\
\hline Anatidae & 1 & 1.4 \\
\hline Apodidae & 1 & 1.4 \\
\hline Ardeidae & 6 & 8.2 \\
\hline Bucerotidae & 2 & 2.7 \\
\hline Capitonidae & 1 & 1.4 \\
\hline Caprimulgidae & 1 & 1.4 \\
\hline Columbidae & 7 & 9.6 \\
\hline Corvidae & 2 & 2.7 \\
\hline Cuculidae & 2 & 2.7 \\
\hline Laniidae & 2 & 2.7 \\
\hline Motacillidae & 1 & 1.4 \\
\hline Musophagidae & 2 & 2.7 \\
\hline Nectariniidae & 8 & 11 \\
\hline Numididae & 2 & 2.7 \\
\hline Phalacrocoracidae & 1 & 1.4 \\
\hline Phasianidae & 3 & 4.1 \\
\hline Phoeniculidae & 1 & 1.4 \\
\hline Picidae & 1 & 1.4 \\
\hline Ploceidae & 9 & 12.3 \\
\hline Podicipedidae & 1 & 1.4 \\
\hline Scopidae & 2 & 2.7 \\
\hline Sturnidae & 2 & 2.7 \\
\hline Total & 73 & 100 \\
\hline
\end{tabular}

ecotorism. Nigerian Journal of Forestry 39(2): 79-91.

2. Clergeau P, Savard JPL, Mennechez G, Falardeau G (1998) Bird abundance and diversity along an urban-rural gradient: a comparative study between two cities on different continents. Condor 100(3): 413-425.

3. Crooks KR, Suarez AV, Bolger DT, Soulé ME (2001) Extinction and colonization of birds on habitat islands. Conservation Biology 15(1): 159-172.

4. Bibby CJ, Burgess ND, Hill DA (1992) Bird Census Techniques. London: Academic Press.

5. Bibby C (1998) Why count birds? In: Bibby C, Jones M, Marsden S (Eds.), Expedition Field Techniques: Bird Surveys. Expedition Advisory Centre. Royal Geographical Society. Kensington, London, pp: 5-11.

6. Rands MRW (1991) Conserving threatened birds: an overview of the species and the threat. In: Perrings CM, Lebreton JD, Hirons GJM (Eds.), Bird Population Studies. Oxford University Press, New York, pp: 581-593.

7. Burnham KP, Anderson DR, Laake JL (1980) Estimation of density from line transect sampling of biological populations. Wildlife Monographs 72: 202.

8. Thakur ML, Paliwal R, Tak PC, Mattu VK (2003) Birds of Balh valley, district Mandi, Himachal Pradesh, India. Anna For 11(1): 113-126.

9. Borrow N, Demey R (2004) Birds of Western Africa. Christopher Helm, London.

Table 2: Status of Bird Families Recorded in the Wetland of Ayede.

\begin{tabular}{|c|c|c|}
\hline & Frequency & Percent \\
\hline Status & & \\
\hline I & 7 & 9.6 \\
\hline R & 66 & 90.4 \\
\hline Abundance & & \\
\hline C & 1 & 1.4 \\
\hline F & 27 & 37 \\
\hline RA & 6 & 8.2 \\
\hline UC & 39 & 53.4 \\
\hline
\end{tabular}

Table 3: Status and Abundance Categories of Bird Species in Ayede Wetland.

$\mathrm{R}=$ Resident, $\mathrm{I}=\mathrm{R}=$ Resident, $\mathrm{I}=$ Immigrant, $\mathrm{RA}=$ Rare, $\mathrm{C}=$ Common, $\mathrm{UC}=$ Uncommon, $\mathrm{f}=$ frequent

\section{References}

10. Afolayan AT, Ajayi SS (1980) The influence of seasonality on the distribution of large mammals in the Yankari Game Reserve, Nigeria. Afr J Ecol 18(1): 87-96.

11. Crowel CM, Schif JC, Gubb AA (1981) Effect of rainfall variation, fire vegetation and habitat physiognomy on Northern Animal Community. South African Wildlife Resources 11(3): 87-104.

12. Moenting AE, Morris DW (2006) Disturbance and habitat use: is edge more important than area? Oikos 115(1): 23-32.

13. Jayson EA, Mathew DN (2002) Structure and composition of two bird communities in the southern Western Ghats. J Bombay Nat Hist Soc 99(1): 8-25.

14. Tack PC, Sati JP, Kumar A (2003) Species richness and seasonal population changes in waterfowls. Zool. Surv. India, fauna of Asia Wetland, Wetland Ecosystem series 5: $43-52$.

1. Ogunyemi 00, Olujobi OJ (2010) Assessment of flora and fauna diversity of Cross River state for sustainable

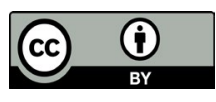

